\title{
Resúmenes Tesis: Doctorado en Física
}

\section{Cambios en las propiedades electrónicas y magnéticas de materiales a base de carbono: Nanotubos y Grafeno}

\section{Carlos Mario Ruiz Tobon}

cmruiz@santafe-conicet.gov.ar

Director / Co-Director: Dr. Sergio Dalosto / Dra. Silvia Tinte

Lugar de realización: IFIS litoral. Facultad de Bioquímica y Ciencias Biológicas. Universidad Nacional del Litoral

Fecha de la defensa: 19/03 /2015

\section{Resumen}

Los materiales a base de carbono como el grafeno y los nanotubos de carbono han despertado gran interés en la comunidad científica y tecnológica por su características físicas y químicas únicas, p.e. conductividad eléctrica y térmica extremadamente alta, resistencia mecánica superior a la mayoría de los materiales conocidos, reactividad química, o simplemente como base en nanomateriales funcionalizados para obtener cualidades específicas. Desde un punto de vista teórico, estas propiedades pueden modelarse con métodos basados en la Teoría del Funcional de la Densidad aunque a un nivel de teoría que incluya adecuadamente las interacciones, en particular, la interacción electrón-electrón. En este trabajo se estudió (i) como el campo eléctrico producido por moléculas de agua cambia las propiedades electrónicas y magnéticas de nanotubos de carbono cortos (CNT-LF). Específicamente analizamos los cambios en el gap electrónico HOMO-LUMO, la posibilidad de llevar el CNT-LF de semiconduc- tor a semimetálico, la densidad de espín, la polarización electrónica y magnética. También, (ii) se estudió en estos CNT-LF la posibilidad de cambiar el estado fundamental antiferromagnético a un estado ferromagnético mediante distorsiones estructurales buscando nanomagnetismo. Esto se realizó para un CNT de $0.56 \mathrm{~nm}$ de diámetro y longitudes de hasta $\sim 3.3 \mathrm{~nm}$. En estos estudios usamos métodos de primeros principios en el formalismo de DFT combinados con campos de fuerza clásicos conocido como QM/MM complementado con simulaciones de Dinámica Molecular clásica. Además, (iii) estudiamos el transporte de moléculas de agua a través de nanocanales, con dimensiones de 0.6 a $1.5 \mathrm{~nm}$ de ancho, construidos con fragmentos de grafeno.

\section{Summary}

Changes in electronic and magnetic properties of carbon-based materials: Nanotubes and Graphene

The carbon-based materials such as graphene and carbon nanotubes have attracted great interest in the scientific and technological community for their unique chemical and physical features, e.g. extremely high electrical and thermal conductivity well above most of the known materials, chemical reactivity, mechanical strength or simply as base for functionalized nanomaterials with specific qualities. From a theoretical point of view, these properties can be 
modeled with the Density Functional Theory but including a well treatment of the electron-electron interaction. In this work, we study (i) how the electric field produced by water molecules changes the electronic and magnetic properties of finite-sized carbon nanotubes (CNT-LF). Specifically we analyze the changes in the electronic HOMO-LUMO gap and the possibility to change the electronic ground state of CNT-LF from semiconductor to semimetal, the spin density, electronic and magnetic polarization. (ii) it was also studied in these CNT-LF, the possibility to change the antiferromagne- tic ground state to a ferromagnetic state by introducing structural distortions looking for nanomagnetism. This was done for a CNT with diameter of $0.56 \mathrm{~nm}$ and lengths that go to $\sim 3.3 \mathrm{~nm}$. We have performed firstprinciples calculations in the DFT formalism combined with classical force fields known as $\mathrm{QM} / \mathrm{MM}$, and supplemented by classical Molecular Dynamics simulations. Also, (iii) we study the transport of water molecules through nanochannels, with dimensions between 0.6 to $1.5 \mathrm{~nm}$ wide, built with fragments of graphene. 